John Carroll University

Carroll Collected

\title{
The Hindenburg disaster: Combining physics and history in the laboratory
}

Gregory A. DiLisi

John Carroll University, gdilisi@jcu.edu

Follow this and additional works at: https://collected.jcu.edu/fac_bib_2017

Part of the Curriculum and Instruction Commons, and the Physics Commons

\section{Recommended Citation}

DiLisi, Gregory A., "The Hindenburg disaster: Combining physics and history in the laboratory" (2017). 2017 Faculty Bibliography. 11.

https://collected.jcu.edu/fac_bib_2017/11 


\section{The Hindenburg Disaster: Combining Physics and History in the Laboratory}

Gregory A. DiLisi, John Carroll University, University Heights, OH

$\mathrm{T}$ his May marks the 80th anniversary of the Hindenburg disaster. On May 6, 1937, the German passenger zeppelin Hindenburg, hovering 300 feet in the air and held aloft by seven million cubic feet of hydrogen gas, burst into flames while preparing to dock at the Naval Air Station in Lakehurst, NJ (Fig. 1). Amazingly, the ensuing fire consumed the massive airship in only 35 seconds! In the aftermath, 35 of 97 people onboard died (13 passengers and 22 crewmen) plus one member of the ground crew. Herbert Morrison, the broadcaster from Chicago's WLS radio station, was on assignment that day covering the arrival of the majestic airship. Morrison's eyewitness account of the disaster is legendary audio history. In fact, Morrison's phrase, "Oh, the humanity!" has become a cultural idiom.

We present the Hindenburg disaster as a case study in the flammability of fabrics. Our goal is to examine the ship's outer covering and decide whether or not it was the fire's initial source of fuel. To accomplish this, we piloted a basic vertical flame test with students in an introductory-level undergraduate laboratory. Our test is patterned after the protocol set forth by the American Society for Testing and Materials (ASTM) for determining the flammability of textiles. The case study provides several unique teaching opportunities.

First, we observe the anniversary of this tragedy by bringing it to the attention of a new generation of students, namely, those currently enrolled in our courses. We provided students with background information on the ship's design, final voyage, and destruction. We used excerpts from Morrison's account to headline sections of our case study to more artistically portray historical events. Reexamining a major historical event is a powerful means of piquing students' interest, particularly those who are more disposed to a liberal arts focus.

Although we piloted this case study in an introductorylevel laboratory setting, its interdisciplinary nature has broad appeal, making it suitable for introductory physics and engineering courses, senior-level courses on engineering ethics, and courses involving flammability or the science of textiles.

The case study emphasizes to students that scientists no longer adopt a strictly passive approach to history. Instead, scientists now take a forensics approach to major historical events, bringing sophisticated analytical tools to scrutinize

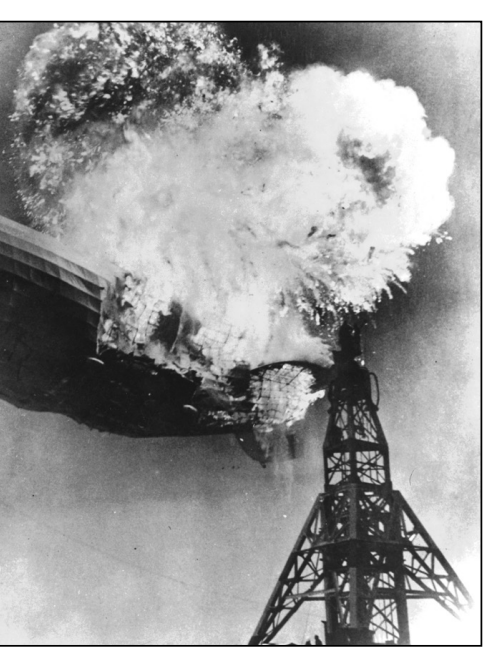

why certain events unfolded. Far from being a set of agreed upon immutable facts, the historical record is open to reexamination and reinterpretation.

The case study also demonstrates to students the "perfect storm scenario" - how a progression of unlikely or unforeseen events often results in a catastrophic failure.

Next, we showcase how scientists and engineers often test analog materials in lieu of actual substances if those substances are prohibitively rare, precious, expensive, or dangerous to test.

Finally, using an ASTM protocol for determining the flammability of textiles demonstrates the importance of operational definitions in scientific experiments. Students will see, perhaps for the first time, that operational definitions involve the comparison of phenomena of interest against a known standard.

\section{"This great floating palace"}

Well, here it comes, ladies and gentlemen ... No wonder this great floating palace can travel through the air at such a speed, with these powerful motors behind it ... The sun is striking the windows of the observation deck on the eastward side and sparkling like glittering jewels on the background of black velvet. ${ }^{1}$

The zeppelin LZ 129 Hindenburg (Luftschiff Zeppelin \#129) was launched on May 4, 1936, as the premier passenger aircraft of the world's first airline, Deutsche LuftschiffahrtsAktiengesellschaft (DELAG), or the German Airship Transportation Corporation. Named in honor of the late President of Germany, Paul von Hindenburg, the ship was the largest zeppelin ever to fly, stretching an incredible $803.8 \mathrm{ft}$ in length and boasting a maximum diameter of $135.1 \mathrm{ft}$. In comparison, the Titanic was $883 \mathrm{ft}$ in length while a modern Boeing 747 is only $250 \mathrm{ft}$. A double-decked gondola, constructed mainly inside the hull to reduce aerodynamic drag, provided passengers with unparalleled luxury: 72 sleeping berths, washrooms, dining room and bar, pressurized smoking room, and spacious lounge. A promenade with slanted windows allowed passengers to gaze upon the scenery below. With four reversible 1200-hp diesel engines and cruising speed of $76 \mathrm{mph}$, the 
airship provided the quickest means of crossing the Atlantic, cutting the typical transit time of contemporary ocean liners in half. $^{2}$

The ship was classified as a rigid airship because of its steel frame. Within the steel structure were 16 large gas cells (or bladders) made of gelatinized latex, designed originally to hold inert helium gas. However, at that time, only the United States, which had stockpiled the nonflammable gas as a byproduct of its mining of natural gas, had enough helium to supply a fleet of airships. Even though the U.S. Helium Control Act of 1927 prohibited American export of helium to any foreign nation, DELAG was hopeful it could convince the U.S. government to export it. Unfortunately, tensions between the United States and Germany deteriorated so the export ban was never lifted. Therefore, DELAG made the decision to trade safety for cost and reengineered the bladders to hold seven million cubic feet of hydrogen as the lifting gas. Converting to hydrogen also had the added benefit of giving the Hindenburg more lift, increasing its capacity to an impressive 242.2 tons of gross lift and 112.1 tons of useful lift. From the ship's control room, the crew could drop water ballast or release hydrogen gas from ventilation shafts along the top of the ship to adjust its buoyancy and trim. Last, the steel structure was covered by panels of cotton cloth doped with various compounds. These panels were stitched together to form a single, and presumably electrically continuous, "skin." The flammability of this outer covering plays a pivotal role in the current debate surrounding the ship's destruction, so we postpone a detailed description of the fabric until later. By May 1937, the Hindenburg was making the first flight of its second season of service, having already completed several safe trans-Atlantic journeys in 1936. Public confidence in hydrogen-filled airships was soaring.

\section{"The ship is riding majestically toward us"}

The ship is riding majestically toward us like some great feather.... It's practically standing still now; they've dropped ropes out of the nose of the ship, and (uh) they've been taken ahold of down on the field by a number of men. It's starting to rain again.

On what would be its final voyage, the Hindenburg left Frankfurt, Germany, at 7:16 p.m. on May 3, 1937, under the command of Captain Max Pruss and First Officer Albert Sammt. This was Pruss's first time commanding the Hindenburg. The ship was scheduled to arrive at Lakehurst, NJ, at 6:00 a.m. on May 6, but unusually strong headwinds caused it to run several hours behind schedule. As the ship approached New Jersey, it encountered a storm before reaching the Lakehurst Naval Air Station at 4:15 p.m. The airfield was under the command of Charles Rosendahl, who radioed the ship to delay landing until weather conditions improved. By 6:22 p.m., the storm had passed but conditions were rapidly worsening. Rosendahl radioed the Hindenburg, recommending "the earliest possible landing."
To understand the Hindenburg's final approach to the Lakehurst Naval Station, note that wind direction refers to the direction from which the wind is coming. Also, navigational directions are denoted as follows: "bow" refers to the front of the ship; "stern" refers to the back of the ship; "port"

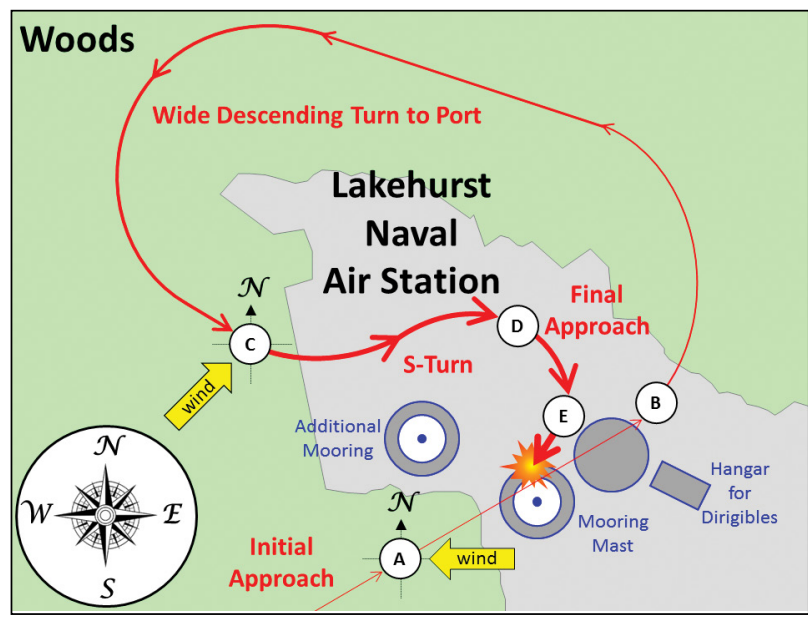

Fig. 2. Approach of the Hindenburg. The thickening red line represents a lowering elevation of the ship.

refers to the left side of the ship (when facing forward); and "starboard" refers to the right side of the ship (when facing forward). Facing an easterly wind, Pruss approached the airfield at 7:08 p.m. from the southwest at an elevation of about $650 \mathrm{ft}$ to observe ground conditions (Fig. 2, Point A). At 7:09 p.m., he initiated a wide descending turn to port in order to dock the ship pointing into the wind. This would maximize the ship's aerodynamic stability as passengers disembarked (Fig. 2, Point B). Sammt lowered the Hindenburg's elevation by releasing hydrogen in 15-second intervals from various ventilation shafts as the ship turned. At 7:16 p.m., Pruss was lining the ship to the east at an elevation of about $400 \mathrm{ft}$ when the wind shifted from easterly to southwesterly, forcing Pruss to again turn the ship for docking, this time facing southwest (Fig. 2, Point C). With deteriorating weather conditions, little room to maneuver, and anxious to land, Pruss decided to execute a tight $\mathrm{S}$-turn rather than make another large looping pass over the airfield. He ordered a sharp turn to port followed by a sharp turn to starboard. Sammt continued to vent hydrogen from various gas cells to lower the ship's elevation to $350 \mathrm{ft}$. At some point prior to, or during this S-turn, the ship began to run heavy in the tail because at approximately 7:18 p.m., Sammt ordered two drops of $300 \mathrm{~kg}$ of water ballast from the stern and valved five seconds of hydrogen from the bow (Fig. 2, Point D). At 7:19 p.m., with the tail still heavy, Sammt ordered one last drop of $500 \mathrm{~kg}$ of water ballast from the stern and sent six crewmen to the front of the ship to help lower the bow. Finally, at 7:21 p.m., the ship was at an elevation of $300 \mathrm{ft}$ and roughly pointed into the wind (Fig. 2, Point E). Although the ship was still heavy in the tail, the forward grounding lines were dropped. A light rain began to fall. The metal frame was now electrically grounded by the landing lines. 


\section{"It's burst into flames!"}

It's burst into flames! ... and it's crashing! It's crashing terrible! Oh, my! .... It's smoke, and it's in flames now; and the frame is crashing to the ground, not quite to the mooring mast. Oh, the humanity! And all the passengers screaming around here .... Listen, folks; I ... I'm gonna have to stop for a minute because I've lost my voice. This is the worst thing I've ever witnessed.

Using eyewitness accounts to determine the origin of the fire proved confusing, but the first sign of trouble appears to have been at the top, rear of the ship, just in front of the vertical fin. ${ }^{3}$ Both R. H. Ward (stationed with the port bow landing party) and R. W. Antrim (stationed atop the mooring mast) testified that they noticed a fluttering of the ship's outer cover at this location - suggesting hydrogen was leaking out of a rear interior bladder against the outer covering. ${ }^{3}$ Crewmen in the control stations of the lower fins testified hearing "muffled detonations" near the top of the ship. When they looked up, they saw bright red and yellow reflections of fire. ${ }^{3}$ By 7:25 p.m., a yellow flame appeared on the outside of the ship at this spot. Within seconds, the tail section was engulfed in flames. The ship managed to stay afloat for a few seconds, but eventually the tail section sank, slamming crew and passengers 15-20 ft backwards into the rear walls of the control room, cabins, dining lounge, and promenade. As the Hindenburg tilted upward, the fire traveled inside the ship along the central axis until a blowtorch of fire erupted from the nose (Fig. 3). Crewmen stationed in the bow were incinerated.

Most eyewitnesses described the Hindenburg as burning from the inside out. Within 30 seconds, the entire ship crashed to the ground and rolled slightly starboard. In general, passengers and crew in the promenade or public areas near the outside of the ship were able to jump to safety while those deeper inside the ship (interior cabins and control stations) did not. Fortunately, many passengers had gathered in the promenade to watch the landing. Some family members lived or died based merely on a few feet of separation. Pruss and Sammt stayed with the ship until it hit the ground. Both men survived the crash, but Pruss was badly disfigured from burns he received carrying crewmen from the wreckage. On the ground, Herb Morrison had been assigned to cover the landing because of his prior work in broadcasting from an airplane. Normally, he would have been in Chicago covering a live musical program. After the tragedy, the 16-inch green lacquer disk recordings of Morrison's account, which were actually damaged by debris from the burning airship, were flown by airplane to Chicago and broadcast that night from radio station WLS. In 1987, a small memorial pad was dedicated on the 50th anniversary of the tragedy. The pad is located on the site where the Hindenburg's gondola landed.

\section{Theories}

Film footage coupled with Morrison's audio account

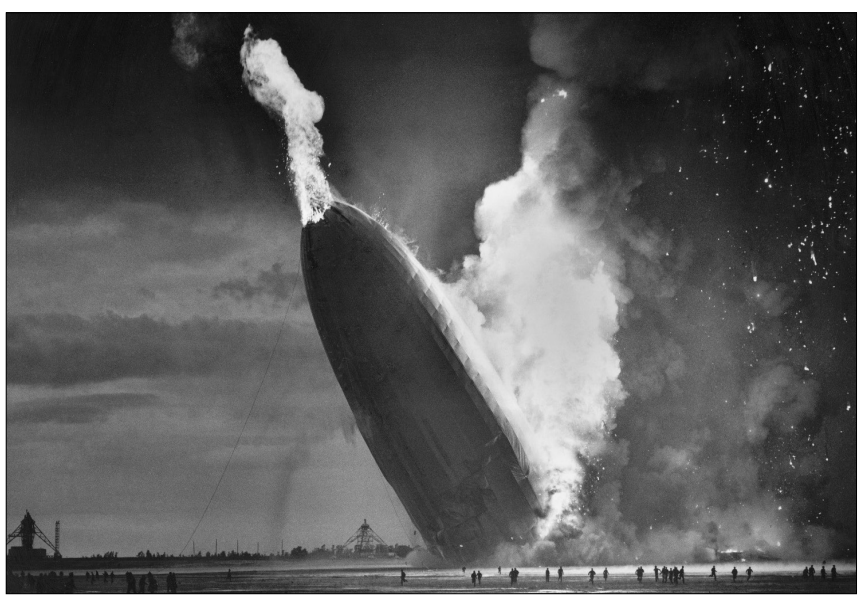

Fig. 3. The final moments of the Hindenburg. As the bow angled upward, a blowtorch of fire erupted out of the nose. (Public Domain)

brought a swift end to the era of zeppelins. The public would never again feel safe aboard one. Subsequent investigations by the United States and Germany were inconclusive in determining the cause of the fire. For years, scientists, politicians, and military personnel put forth several theories as to the underlying causes of the disaster. Was it sabotage? No evidence of sabotage was ever found. Was it a lightning strike? Unlikely - the outer covering of the ship had several burn holes, some as large at five centimeters in diameter, proving the ship had survived in-flight lightning strikes during its first year of service. ${ }^{4}$ Today, a reexamination of the evidence leaves us with two competing theories that at least agree on the fire's source of ignition. As the Hindenburg passed through the storm off the New Jersey coast, it became electrically charged. When the landing lines touched the ground prior to docking, they "earthed" the Hindenburg's steel frame but not every panel of the ship's fabric covering. A spark between the charged panel of fabric and the grounded steel frame ignited some source of fuel. The difference between the two theories lies in identifying that source of fuel.

- Leaking hydrogen gas: The most likely explanation of events is that the electrostatic discharge ignited leaking hydrogen gas. Recall that during the sharp S-turn, Sammt was unable to correct the ship's trim. Experts agree that the ship was undoubtedly leaking hydrogen from the stern. ${ }^{3}$ What caused the leak? One theory suggests that the S-turn was uncommonly tight and that one of the rudder's bracing cables may have been overstressed to the point where it snapped and slashed through a gas cell. ${ }^{5}$ Maybe something as simple as a sticky valve was at fault. Regardless of the cause of the leak, an explosive mixture of hydrogen gas and air floated above the ship's tail. Because this theory blames the ship's demise on the decision to land after the storm and on the S-turn made just prior to docking, it was strongly refuted by Pruss and Rosendahl, both of whom always maintained the ship fell victim to sabotage. 
- Incendiary paint: In 1997, engineer Addison Bain put forth the idea that at least early in the fire, the ship's outer covering itself, and not leaking hydrogen gas, was the primary source of fuel for the fire. ${ }^{6}$ The cotton cloth that covered the ship was doped with different mixtures based on cellulose acetate butyrate $(\mathrm{CAB})$, the base resin for what are commonly called lacquers. The portion of cloth covering the lower half of the ship was doped with a layer of pure $C A B$, then three layers of $C A B$ mixed with aluminum powder. The portion of cloth covering the upper half of the ship was doped with a layer of pure $C A B$, a layer of $C A B$ mixed with iron oxide, and three layers of $C A B$ mixed with aluminum powder. These coatings gave the ship its distinctive reflective appearance and were used to keep the outer skin taut for aerodynamic purposes as well as to protect it from wind, water, and small objects. The added layer of iron oxide on the upper portion of the ship protected the interior gas bags from damage by UV radiation and overheating from IR radiation. Bain developed his theory when he realized that these compounds are similar to the components of thermite, a pyrotechnic composition that resembles a common sparkler or the propellant in the space shuttle's solid rocket boosters. In short, Bain argued that the Hindenburg's outer skin was essentially a gigantic sparkler. According to Bain, the electric discharge was energetic enough to ignite the skin and cause a dramatic exothermic reduction-oxidation reaction; therefore, this idea has become known as the "Incendiary Paint Theory" (IPT). The IPT has merit for two reasons: (i) Hydrogen burns with an invisible flame, yet the Hindenburg was consumed in an enormous yellow and red fireball. One might conclude that something other than hydrogen was burning. (ii) The ship held its position for a few seconds before the stern crashed to the ground. One might conclude that the gas cells were intact when the fire started. To test his idea, Bain obtained an actual remnant of fabric from the Hindenburg and ignited it with a continuous spark. The piece burned as a brilliant yellow burst that looked like a miniature version of the Hindenburg disaster. ${ }^{7}$

\section{Combining physics and history in the laboratory}

We used the IPT as the basis of a new, inexpensive lab activity focusing on a previously untapped topic in our course, namely the flammability of fabrics. Since the IPT posits that the propagation of the fire was due to burning of the Hindenburg's fabric, we designed an investigation to quantify how fabrics burn after the source of ignition is removed. Our activity is modeled after the vertical flame test, ASTM D 6413-99 - The Standard Test Method for Flame Resistance of Textiles (Vertical Test), which has been adopted as an accepted federal test standard. ${ }^{8}$ This protocol is considered to be the most fundamental and commonly used test on flame resistant fabrics in the United States. To align with the ASTM protocols, English units are used throughout the analysis. The equipment and materials needed to create this activity cost under $\$ 30$ and were readily obtained from local hardware, fabric, and automotive refinishing stores. We piloted our activity on a cohort of undergraduate students. We started by presenting students with the historical background information described in the previous sections. Next, we emphasized two concepts: (i) The goal of our activity is not to prove or disprove the IPT, but to showcase how physics can be used in the real world, and (ii) Even though our activity focuses only on a vertical flame test, it gives us a quantitative understanding of how flammability is tested and how results can be used to unravel the Hindenburg disaster (obviously, combining our results with those from a horizontal flame test would provide a more complete analysis).

- Sample preparation: Because purchasing chemicals is expensive and heavily regulated, reproducing the Hindenburg's outer fabrics is simply not possible for most teachers. Instead, we chose to test three fabrics that were easy to make and inexpensive to buy, yet nicely approximate the outer coverings of the airship. First, we purchased swatches of pure cotton cloth and ironed them. Next, we purchased clear lacquer, black primer with iron oxide as its tinting agent (iron oxide black pigment, in powder form, can also be purchased online), and a concentrated aluminum resin paste (our specific type was Genesis LV 1060 from Sherwin-Williams Paints). To create the fabric that approximates the covering on the upper portion of the ship, we rolled cotton swatches with a layer of clear lacquer, then a layer of black primer, then three layers of aluminum paste. To create the fabric that approximates the covering on the lower portion of the ship, we rolled cotton swatches with a layer of clear lacquer, then three layers of aluminum paste. After the coatings dried, we were left with samples of pure cotton cloth and two stiff, reflective fabrics that approximate the fabric on the lower and upper portions of the Hindenburg. Students trimmed each of these three samples into five strips ( 12 in $\mathrm{x} 3$ in) and weighed each strip. Each strip was placed into a frame of sheet metal that secured the strip on two sides, leaving the bottom edge exposed. The frame was clamped together at four locations and suspended in a laboratory hood.

\section{- Testing: A flat black poster background and dimmed} lights were used to enhance observation of burning fabrics inside the hood. Precautions were taken to minimize drafts in the hood. No attempt was made to control ambient temperature or pressure. No attempt was made to move the strips nor to test a horizontal orientation of the strips. Each strip was tested and the average of five strips was reported per fabric. A Bunsen burner, with $10-\mathrm{mm}$ inside diameter barrel, was used to create a 1.5-in high 99\%-pure methane flame. The burner could be swiveled so that the exposed edge of the strip was exactly 0.75 in above the top of the burner. The flame was applied for $12 \pm 0.25 \mathrm{~s}$ (flame-to-strip), as measured by a stopwatch. Students filmed each trial using cell phone cameras in "slow motion" mode [Fig. 4 (a)]. Once the flame was removed, students continued to film the strip until any visual flame or glow self-extinguished [Fig. 4(b) and (c)]. These vid- 

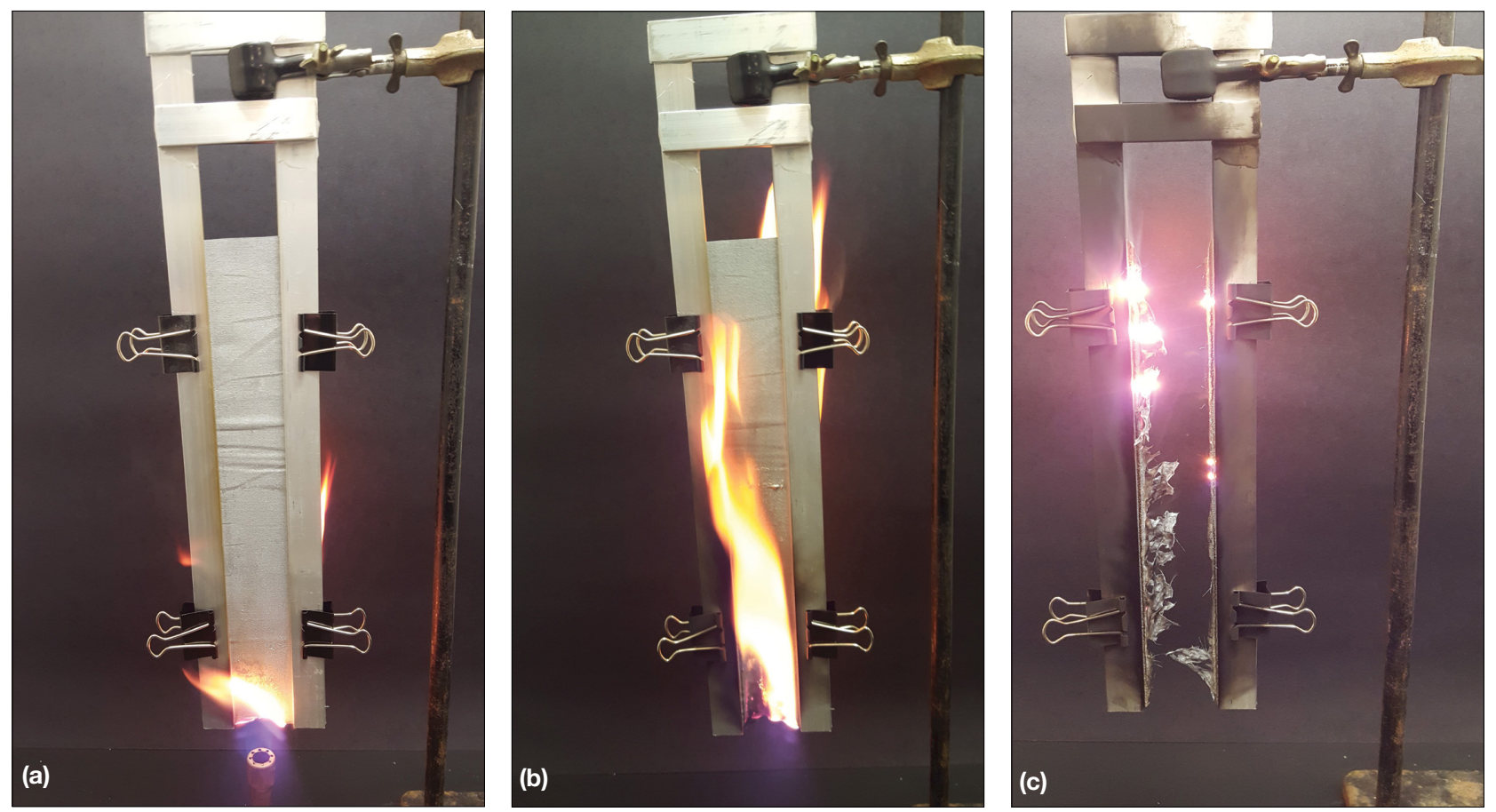

Fig. 4. Our apparatus for vertical flame testing. (a) Start of flame test. (b) Afterflame. (c) Afterglow.

eos would be used only to determine the duration of time, to 0.1 -s resolution, that the samples burned and/or glowed. Any signs of melting or dripping were noted. If a portion of the strip remained intact, the strip was removed from the metal frame so that students could apply the following specific tearing force to the strip: A crease was made running lengthwise through the peak of the highest charred area and parallel to the side of the strip. A hook was inserted into the strip 0.25 in from the charred edge. A weight was attached to the hook depending on the strip's weight per unit area (100 $\mathrm{g}$ for strips $68-203 \mathrm{~g} / \mathrm{m}^{2} ; 200 \mathrm{~g}$ for strips $204-508 \mathrm{~g} / \mathrm{m}^{2} ; 300 \mathrm{~g}$ for strips $509-780 \mathrm{~g} / \mathrm{m}^{2}$; and $400 \mathrm{~g}$ for strips over $780 \mathrm{~g} / \mathrm{m}^{2}$ ). With the hook in place, students grabbed the other side of the charred edge and raised the strip in a smooth, continuous motion until the tearing of the strip along the crease stopped. Many strips were totally consumed by the vertical flame so tearing the strip was not necessary [Fig. 4(c)].

- Analysis: Using their video clips and a ruler, students determined or calculated the following:

- "Afterflame," the time when a visible flame remained on the strip, as determined from the cell phone video clips.

- "Afterglow," the time when a visible glow remained on the strip, as determined from the cell phone video clips.

- "Char length," the distance from the exposed edge of the strip to the furthest point of visible damage after the tearing force was applied, as determined by measuring the damaged portion of the strip with a ruler. Note that the char length is 12 in if the strip is totally consumed by the fire.

- "Vertical burn rate," calculated as the char length divided by the afterflame.
- "Vertical burn time" (designated as $t_{\text {lower }}$ or $t_{\text {upper }}$ ), the time, extrapolated from the vertical burn rate, needed to burn a 106.1-ft long swatch of the strip (i.e., $1 / 4$ of the Hindenburg's maximum circumference). Because the upper and lower portions of the ship were covered in different fabrics, the maximum vertical distance a fabric could burn is $\sim 1 / 4$ the maximum circumference of the ship.

- “Total vertical burn time," the total time needed to burn vertically one entire side of the ship. This time was determined by adding the vertical burn times for the fabrics covering the lower $\left(t_{\text {lower }}\right)$ and upper $\left(t_{\text {upper }}\right)$ portions of the ship.

- Results: Table I shows data from a typical run of our activity. Results support the notion that leaking hydrogen, and not incendiary paint, is the most plausible source of fuel for the fire that consumed the Hindenburg. The outer fabrics just do not burn at a fast enough rate to consume a ship the size of the Hindenburg in a timeframe of the order of a minute. After burning strips of pure cotton cloth, students dramatically see that the dopants used on the Hindenburg's fabric actually retard the spreading of fire. The dataset below shows that a fire would need $\sim 112$ minutes to burn a distance roughly equal to the height of the ship, that is to say, from the underside to the topside of the ship. Experiments conducted by A. J. Dessler on horizontal burn rates support our results and show a fire would need 11-12 hours to burn a distance roughly equal to the length of the ship. ${ }^{9,10}$ Dessler discounts the two merits of the IPT explaining that the yellow fireball was actually the fabric, wires, and steel girders burning with visible flames in the invisibly burning hydrogen (as a mantle burns visibly in a lantern, even though the gas that is actually burning may be 
Table I.

\begin{tabular}{|c|c|c|c|c|c|c|}
\hline $\begin{array}{c}\text { Weight } \\
\text { per Area } \\
\left(\mathbf{g} / \mathbf{m}^{2}\right)\end{array}$ & $\begin{array}{c}\text { Afterflame } \\
\text { (s) }\end{array}$ & $\begin{array}{c}\text { Afterglow } \\
\text { (s) }\end{array}$ & $\begin{array}{c}\text { Char } \\
\text { Length } \\
\text { (in) }\end{array}$ & $\begin{array}{c}\text { Dripping } \\
\text { or } \\
\text { Melting }\end{array}$ & $\begin{array}{c}\text { Vertical } \\
\text { Burn } \\
\text { Rate } \\
\text { (in/s) }\end{array}$ & $\begin{array}{c}\text { Vertical Burn } \\
\text { Time } \\
\text { (min) }\end{array}$ \\
\hline 114.8 & 4.1 & 5.5 & 12 & No & 2.9 & 7.3 \\
\hline \multicolumn{7}{|c|}{ Cotton cloth } \\
\hline 287.0 & 30.1 & 32.4 & 12 & No & 0.40 & $\begin{array}{c}t_{\text {lower }} \\
=53.2\end{array}$ \\
\hline \multicolumn{7}{|c|}{ Approximation of fabric covering lower portion of ship } \\
\hline 344.4 & 33.4 & 36.8 & 12 & No & 0.36 & $\begin{array}{c}t_{\text {upper }} \\
=59.1\end{array}$ \\
\hline
\end{tabular}

invisible). Also, as the hydrogen burned the outer fabric and rushed out of the bladders, air rushed in. This created updrafts at the tail of the ship that were strong enough to keep the ship momentarily afloat-just as a burning piece of paper is lifted by the updraft created by its own fire. Finally, a 2007 episode of the popular show "Myth Busters" (Episode 70 - "The Hindenburg Mystery") found similar results and suggested that the IPT, at least in the open sources, is doubtful. ${ }^{11}$ Although the episode is not peer reviewed and should be viewed with some skepticism, it is a phenomenal visual resource available to any teacher and can be shown to students to emphasize or solidify certain concepts. The episode serves as a good closure activity and can be downloaded from iTunes for $\$ 1.99$.

\section{Conclusion and future considerations}

The 80th anniversary of the Hindenburg disaster presents a compelling case study that brings powerful teaching opportunities to a variety of disciplines. First, the anniversary raises historical awareness in our students while bringing real world applications of physics to them. Next, the physics of flammability can be treated appropriately at the introductory level since only careful measurements of time, distance, and weight are needed. In fact, our case study can serve as a start-of-the-semester laboratory exercise where safety, measurement, and error analysis are emphasized. Conversely, our case study can also serve as a capstone project in a senior-level engineering course after which each student is required to examine another engineering failure from history (e.g., Chernobyl, Three Mile Island, the collapse of the Tacoma Narrows Bridge, the Challenger disaster, etc.) and design an experiment with relevant operational definitions to test proposed hypotheses. Third, the resulting analysis shows students that just as scientific theories are open to reexamination in the light of new or confounding observations, so too are historical events open to revisitation and scrutiny. Next, the case study demonstrates to students how a cascade of unlikely events can result in an unpredictable catastrophe and how scientists and engineers often test proxies when actual materials are unavailable or prohibitive to examine directly. Finally, our case study perhaps provides the first opportunity to introduce students to testing standards and how the responses of materials and products are determined.

\section{Acknowledgments}

The author acknowledges James DeLuca, chemist extraordinaire, for his insights into sample preparations. The author also acknowledges the reviewers of this manuscript, who significantly strengthened the presentation of this work.

\section{References}

1. H. Morrison, WLS Radio (Chicago), Address on the arrival of the airship Hindenburg [transcription of audio file], Lakehurst, NJ (May 6, 1937).

Retrieved from http://www.americanrhetoric.com/speeches/ hindenburgcrash.htm on Jan. 3, 2017.

2. B. Waibel, The Zeppelin Airship LZ 129 Hindenburg, (L.E.G.O.S.p.A., Italy, 2013), pp. 7-22.

3. Bureau of Air Commerce, Air Commerce Bulletin of August 15, 1937, Vol. 9, No. 2 (United States Department of Commerce, Washington, DC, 1937), pp. 28-29.

4. R. Archbold, Hindenburg: An Illustrated History (Warner Books, New York, 1994).

5. T. Graham, "Hindenburg: Formula for disaster," ChemMatters (Dec. 2007). Retrieved from https://www.acs.org/content/ dam/acsorg/education/resources/highschool/chemmatters/ articlesbytopic/biographyandhistory/chemmatters-dec2007hindenburg.pdf on Jan. 3, 2017.

6. A. Bain, "Colorless, nonradiant, blameless: A Hindenburg disaster study," Gasbag J./Aerostation 39 (March 1999).

7. Kurdistan Planetarium, "What Happened to the Hindenburg?" Retrieved from https://www.youtube.com/watch?v=phZI_ h3Q4V0 on Jan. 3, 2017.

8. American Society for Testing and Materials, ASTM D 6413-99, Standard Test Method for Flame Resistance of Textiles (Vertical Test), Annual Book of ASTM Standards (ASTM, West Conshohocken, PA, 2016).

9. A. J. Dessler, D. E. Owens, and W. H. Appleby, “The Hindenburg fire: Hydrogen or incendiary paint?” Buoyant Flight 52 (2/3) (Jan./Feb. and March/April 2005).

10. A. J. Dessler, “The Hindenburg hydrogen fire: Fatal flaws in the Addison Bain incendiary paint theory," Lunar and Planetary Laboratory, University of Arizona, Tucson, AZ (June 3, 2004). Retrieved from http://spot.colorado.edu/ dziadeck/zf/LZ129fire.pdf on Jan. 3, 2017.

11. "MythBusters: Hindenburg MiniMyth.” Retrieved from http:// www.discovery.com/tv-shows/mythbusters/videos/ hindenburg-minimyth/ on Jan. 3, 2017.

Gregory A. DiLisi is currently an associate professor at John Carroll University, where he teaches physics, science methods, and instructional technology courses. As an experimental physicist, he specializes in liquid crystals, with his recent research focusing on stabilizing liquid bridges that shift from micro- to hyper-gravity environments. In the area of science education, his research has focused on problem solving and team building in engineering and the sciences. gdilisi@jcu.edu 